\title{
Analisis Manifestasi Segragasi Politik Pelabelan dan Polarisasi di antara Kelompok Islam Sepanjang 2014-2019
}

\author{
Romel Masykuri ${ }^{I}$ dan M. Fajar Shodiq Ramadlan ${ }^{2}$ \\ ${ }^{I}$ Pusat Kajian Media, Literasi dan Kebudayaan, Universitas Brawijaya \\ ${ }^{2}$ Program Studi Ilmu Politik, Universitas Brawijaya
}

\begin{abstract}
Abstrak:
Politik pelabelan merefleksikan dan mengekspresikan polarisasi dan kontestasi di antara kelompok Islam dalam politik. Label politik menjadi instrumen dan strategi untuk membangun citra dan persepsi dalam kontestasi dan konstelasi politik di Indonesia. Artikel ini menjelaskan bagaimana kontestasi di antara kelompok Islam termanifestasi melalui label untuk merebut klaim dan legitimasi politik. Metode process-tracing dan analisis konten digunakan untuk mengidentifikasi dan menjelaskan label di antara kelompok Islam. Selama 20I4-20I9, ada dua isu penting terkait politik pelabelan. Pertama, label berhubungan dengan konteks, hubungan kausalitas, dan tujuan atau konsekuensi dari pelabelan. Label merefleksikan pembingkaian tertentu dan pembeda antara kelompok. Kedua, segregasi dan polarisasi politik di antara kelompok-kelompok Islam selama 20I4-20I9 di Indonesia termanifestasi melalui konstruksi dan produksi berbagai label. Melalui label, sentimen agama dan perbedaan antar kelompok Islam menjadi instrumen untuk mobilisasi atau menggerus dukungan politik lawan dalam politik elektoral.
\end{abstract}

Keywords:

politik pelabelan; segregasi politik; kelompok Islam

\section{Pendahuluan}

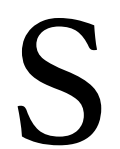

egregasi politik dalam kelompok Islam merupakan fenomena yang terjadi sejak lama dan dinamis. Di Indonesia, hal itu dapat diamati melalui berbagai polarisasi dan fragmentasi di antara organisasi kelompok Islam, baik berbasis aliran, model organisasi, maupun orientasi sosialpolitik. Dalam pandangan soal bentuk dan landasan negara, misalnya, sejak awal kemerdekaan kelompok-kelompok Islam mempunyai tafsir beragam terhadap hubungan agama dan negara (Hosen, 2005). Bahkan, eksistensi kelompok Islam juga terefleksi dalam kontestasi elektoral, di mana tiga partai Islam: Masyumi, Nahdlatul Ulama (NU), dan Partai Syarikat Islam Indonesia (PSII), dengan basis akar rumput yang kuat saling bersaing dalam pemilu 1955 (Orde Lama).

\section{Korespodensi:}

Prodi Ilmu Politik, Universitas Brawijaya, Jl. Veteran Malang Jl. Universitas Brawijaya, Ketawanggede, Kec. Lowokwaru, Kota Malang, Jawa Timur 65145.

Email: fajarramadlan@ub.ac.id 
Ketika Orde Baru, dinamika perkembangan kelompok Islam dan keterkaitan dengan politik memperoleh tekanan rezim. Isu-isu politik yang berkenaan dengan agama tidak banyak dibicarakan (Hasan, 2008). Identitas agama dalam partai politik juga mengalami pembonsaian dengan direduksinya 4 partai Islam (Partai NU, Parmusi, Perti dan PSII) ke dalam Partai Persatuan Pembangunan (PPP). Pembatasan ini juga diikuti dengan pembatasan aktivitas pendirian organisasi Islam (Porter, 2004). Baru pada I990-an, masyarakat Islam mulai lebih banyak mengekspresikan identitas keislamannya melalui simbol-simbol organisasi, cara berbusana, serta munculnya tokoh-tokoh Islam di kancah nasional yang kemudian dihimpun dalam Ikatan Cendekiawan Muslim Indonesia (ICMI) (Hasan, 2008).

Pasca Reformasi, ruang eksistensi kelompok Islam dalam politik makin berkembang dan jauh lebih terbuka. Berakhirnya rezim Orde Baru dan diikuti dengan demokratisasi, yang meliputi pelembagaan demokrasi, seperti perkembangan sistem pemilihan umum (pemilu); tumbuhnya jumlah partai politik; desentralisasi; serta transfer nilai-nilai demokratis, seperti kebebasan berpendapat; berorganisasi dan berserikat, menjadikan kelompok Islam turut mengalami perkembangan (King, 2003). Muncul berbagai organisasi Islam yang menyuarakan narasi politik yang beragam. Termasuk isu-isu yang berkenaan dengan Islam politik, seperti upaya memperdebatkan kembali relasi agama-negara, relasi Islam-Pancasila, penerapan syariat Islam, serta narasi pendirian negara Islam (Azra, 2004; Hasan, 2008; M. R. Karim, 1999).

Perkembangan narasi tentang politik Islam makin menguat seiring dengan tumbuhnya keanggotaan dalam kelompok Islam, seperti Tarbiyah dan Hizbut Tahrir Indonesia (HTI), di samping Nahdlatul Ulama, Muhammadiyah, Persatuan Islam (Persis), Lembaga Dakwah Islam Indonesia (LDII), dan organisasi kelompok Islam lain yang telah berkembang sebelumnya. Sejalan dengan hal itu, partai politik dengan platform keislaman dan berbasis massa muslim juga berkembang, seperti Partai Keadilan Sejahtera (PKS), Partai Kesatuan Bangsa (PKB), Partai Amanat Nasional (PAN), dan Partai Persatuan Bulan Bintang (PBB).

Perkembangan organisasi Islam dan jumlah anggotanya, diikuti menguatnya ikatan individu di dalamnya, turut membentuk pandangan dan orientasi pilihan politik elektoral (Ambardi, Mujani, \& Liddle, 20I2). Paling tidak hal tersebut dapat diamati di tahun 20I4. Kontestasi politik terasa kuat dengan hanya menghadirkan dua pasangan kandidat, yakni Joko Widodo-Jusuf Kalla dan Prabowo Subianto-Hatta Rajasa pada pemilihan presiden (Pilpres) 20I4. Hal tersebut berimplikasi pada munculnya segregasi antar pendukung kandidat. Salah satu cara melihat segregasi adalah melalui praktik pelabelan di antara pendukung. Label "cebong" disematkan kepada pendukung Jokowi, dan label "kampret" disematkan kepada pendukung Prabowo. 
Kontestasi antara Joko Widodo (Jokowi) dan Prabowo kembali terulang pada Pilpres 20I9. Jokowi berpasangan dengan Ma'ruf Amin, sedangkan Prabowo bersanding dengan Sandiaga Uno. Dengan kembali hanya diikuti oleh dua pasangan kandidat seperti pada pemilu sebelumnya, polarisasi antar kelompok pendukung dua kubu kembali menguat. Ketegangan antar pendukung, bahkan terasa di tahun-tahun sebelum adanya penetapan resmi calon presiden dan calon wakil presiden. Label, dalam pemilu 2019 kembali menjadi cara mengekspresikan segregasi antar kelompok, misal dengan penyebutan "partai setan" dan "partai Allah", "ulama yang jadi Cebong” atau "Kadrun".

Diluar Pilpres, fenomena serupa dapat dilihat juga pada Pilkada DKI Jakarta 2017. Label menjadi alat penanda kepada sebagian kelompok Islam. Misalnya, label "muslim munafik", ditujukan kepada warga muslim pendukung dan pemilih Basuki Tjahaja Purnama (Ahok) yang berlatar belakang Tionghoa-Kristen. Sebagai petahana, Ahok dianggap melakukan penistaan terhadap Islam ketika dirinya menyinggung surat Al-Maidah (Tempo.co, 2017).

Dalam rentang waktu 20I4-20I9, segregasi tampak di antara dua kelompok pendukung, khususnya kelompok Islam yang terlibat dalam mobilisasi dukungan kepada masing-masing kandidat. Interaksi antar kelompok Islam salah satunya diekspresikan melalui pelabelan antar kelompok Islam yang lain. Pelabelan, serta penanda simbolik yang lain bahkan bekerja dan bisa terlihat di dalam satu kelompok yang sama (kelompok Islam) (Aspinall, Dettman, \& Warburton, 20II; A. G. Karim, 2019). Masing-masing menyuarakan klaim sebagai kelompok Islam paling benar seraya menyuarakan dukungan terhadap masing-masing kandidat.

Fenomena politik pelabelan (politics of labelling) oleh kelompok-kelompok Islam inilah yang menjadi fokus dalam artikel ini. Politik pelabelan menjadi instrumen mengidentifikasi dukungan politik, upaya mobilisasi dukungan, cara menyerang citra kelompok lain, serta menunjukkan orientasi pilihan politik dan kebijakan. Pelabelan mewarnai penyebaran pesan dan konten politik di sepanjang tahun 2014-2019.

Metode yang digunakan dalam artikel ini mencakup analisis konten dan process-tracing. Teknik analisis konten yang digunakan adalah pada riset kualitatif (Schreier, 2012), di mana informasi atau data tertulis, data verbal, dan data visual, yang diperoleh melalui media kemudian dianalisis, ditafsirkan dan dideskripsi maknanya. Teknik analisis konten umumnya diterapkan ketika peneliti perlu memproses data yang diperoleh dari dokumen, media, dan sumber-sumber daring. Teknik kedua adalah process-tracing (telisik proses), yakni teknik melacak dan mengidentifikasi kausalitas (sebab-akibat) dari satu aspek terhadap aspek lain, atau bagaimana satu proses memiliki hubungan kausal terhadap proses yang lain. Tujuannya adalah untuk memperoleh pemahaman yang lebih besar tentang dinamika kausalitas dalam kasus atau isu tertentu (Beach, 20I7).

Artikel ini menjelaskan bagaimana sebuah label terhadap kelompok Islam yang lain muncul dan digunakan, serta bagaimana pelabelan merefleksikan segregasi 
di kalangan kelompok Islam. Terdapat beragam pelabelan sepanjang tahun 2014 hingga 2019. Adapun label yang ditelusuri bersandar pada tiga kriteria yang diidentifikasi pada artikel ini. Pertama, label yang muncul di ruang publik, misalnya melalui spanduk, baliho atau selebaran. Kedua, label yang diucapkan oleh tokoh politik yang merepresentasikan kelompok atau organisasi Islam. Ketiga, label yang muncul di website resmi atau berafiliasi jelas dengan kelompok atau organisasi Islam.

\section{Politik Pelabelan}

Politik kerap berkenaan dengan persepsi dan senantiasa berkenaan dengan citra (image). Hal ini menjadi cara bagaimana pemilih membentuk penilaian pada kandidat dan partai politik, memengaruhi respon warga terhadap sebuah kebijakan, atau cara pandang terhadap politik secara luas (Backes, 2007; Sajjad, 2018; Wood, 2017). Bagaimana persepsi terbentuk dan cara pandang terhadap image berkenaan dengan berbagai faktor, seperti wilayah, faktor obyektif, faktor subyektif atau faktor temporal. Faktor obyektif misalnya, berkenaan dengan konteks politik, obyek kekuasaan, kewenangan politik. Sedangkan faktor subyektif dapat berkenaan dengan gender, agama, pendidikan, dan kondisi psikologis (Shestopal, 20I4). Image dan persepsi dalam konteks politik tersebut dikemas dalam label. Hal ini kemudian merujuk pada terminologi politik pelabelan.

Pelabelan (labelling) adalah proses yang meresap (pervasive), terjadi pada level yang berbeda dan dalam arena yang berbeda dari sebuah interaksi. Bukan saja antara negara dengan masyarakat, tetapi juga antara masyarakat melalui konstruksi sosial dan identitas tertentu. Pelabelan pada akhirnya juga berkenaan dengan abstraksi dan aktualitas individu atau kelompok, serta pembentukan stereotip melalui penggunaan metafora (Wood, 20I7).

Proses pelabelan berkenenaan dengan istilah-istilah yang digunakan untuk "penamaan" dalam opini publik, terhadap aktor politik, kebijakan atau tindakan politik. Dalam studinya, Backes (2007) menjelaskan bagaimana pelabelan digunakan dengan mengkategorikan sikap politik dari seorang atau sekelompok aktor politik di Eropa. Kelompok-kelompok dengan sikap politik atau ideologi yang kuat, disebut sebagai "ekstrim", "ekstrimis" atau "esktrimisme". Penamaan tersebut kemudian mengerucut pada kategori "anti-demokratisme" atau "anti-konstitutionalisme". Proses penamaan ini digunakan dalam argumentasi dan kampanye politik, khususnya dengan menggunakan kosa kata yang cenderung agresif. Tujuannya adalah untuk merendahkan lawan politik, memberi stigma, dengan menggunakan pembingkaian (framing) tertentu. Dalam pertarungan wacana, pihak yang memberikan label pada kelompok atau lawan politiknya, seolah-olah normal, berada pada sisi yang benar, dan berupaya memperoleh legitimasi mayoritas.

Dalam konteks lain, pelabelan juga berkeenaan dengan proses pembuatan kebijakan. Studi Tazreena Sajjad (2018) menunjukkan bagaimana proses pelabelan terhadap warga Afghanistan pencari suaka di Eropa, menentukan proses pembuatan 
dan pengambilan kebijakan oleh beberapa negara Eropa terhadap mereka. Penggunaan label antara "migrant" (imigran) dan "refugee" (pengungsi), misalnya, berimplikasi pada keputusan negara untuk membuat kebijakan dan mengambil tindakan. Meski merujuk pada konteks warga yang sama, tetapi label mengubah realitas, menentukan siapa yang akan diberi suaka dan perlindungan, serta siapa yang ditahan dan dideportasi. Dalam konteks yang lebih luas tentang bagaimana imigrasi warga Muslim di Eropa, penggunaan label juga mengekspresikan identifikasi sebagai 'korban', 'ancaman' sosial, budaya dan medis, masalah keamanan, dan stabilitas.

Tindakan melakukan klasifikasi atau taksonomi ini merupakan perilaku mendasar dalam interaksi manusia. Proses klasifikasi berkenaan dengan banyak hal, seperti nilai, minat, preferensi, ingatan dan lain-lain. Proses ini terjadi secara simultan salah satunya melalui proses interaksi simbolis. Dengan cara inilah sebuah relasi dapat menetap pada suatu pola (Wood, 2017). Dalam konteks tersebut, pelabelan sebagai proses "penamaan" termanifestasi dalam hampir semua interaksi, baik dalam bentuk gambar, stereotip, metafora, sebagai tanda untuk memandu persepsi dan dengan demikian membentuk perilaku interaksional.

Rosalind Eyben (2007) menjelaskan terdapat tiga hal penting dalam politik pelabelan. Pertama, pelabalen dalam politik melibatkan hubungan kekuasaan, di mana aktor menggunakan frame dan label untuk mempengaruhi bagaimana isu dan kategori orang atau kelompok tertentu dipersepsi dan dikategorisasikan. Framing dalam hal ini mengacu pada bagaimana kita memahami sesuatu sebagai masalah, yang mencerminkan bagaimana sebuah masalah terwakili atau tidak terwakili dalam sebuah wacana atau isu tertentu. Sedangkan label sendiri, mengacu pada bagaimana orang atau kelompok ditandai, diberi nama atau dikategorikan, baik oleh diri sendiri maupun orang lain dengan tujuan mencerminkan citra atau persepsi tertentu. Dalam hal ini berarti bahwa proses pelabelan maupun pembingkaian terkait dengan distribusi kekuatan sosial, politik dan ekonomi.

Kedua, karena kekuasaan memiliki banyak sisi dan tidak searah, ada beragam motivasi maupun cara dalam pelabelan, termasuk dari hasil pelabelan itu sendiri. Meskipun labelling dan framing dapat dikalkulasi dan dimanipulasi, tetapi hasilnya bisa saja tidak seperti yang diprediksi atau diinginkan. Pelabelan dengan niat jahat misalnya, secara tidak terduga dapat berpotensi justru menjadikan kelompok yang diserang memperoleh simpati, menjadikan mereka menguasai klaim-klaim politis dan ruang-ruang politik. Contoh kasus ini misalnya pada persoalan masyarakat miskin, pengungsi atau imigran.

Ketiga, pelabelan dan pembingkaian melibatkan hubungan yang kompleks, beragam, dapat saling melengkapi dan saling bertentangan. Hal ini karena pemilihan label dan frame mempunyai implikasi dalam konteks yang berbeda. Selain itu juga berkenaan dengan ruang yang menyediakan klaim dan kontestasi label. Hal ini misalnya, dapat dilihat pada bagaimana label yang disematkan pada seorang aktor 
politik atau kelompok tertentu, bisa bermakna berbeda di satu media dengan media lain, salah satunya melalui proses framing.

\section{Label dan Frame}

Label mempunyai dimensi yang terdiri dari banyak bagian (multiple) dan saling berkaitan (interrelated) dan dibentuk oleh beragam frame, motivasi dan tujuan. Sebagai strategi, label bukan sekedar sejumlah kualifikasi yang terisolasi. Agar label menjadi efektif, kredibel, dan dianggap sebagai refleksi dari bagian realitas yang dapat diandalkan, label harus membentuk bagian dari rantai argumen rasional. Rasionalitas dan rasionalisasi menjadikan label menjadi sebagai obyektif dan dapat diterima (Wood, 1985).

Merujuk pada Foucault, rasionalisasi dan normalisasi (serta institusionalisasi, subjektivitas, dan personifikasi), adalah manifestasi dari proses kekuasaan dan terkoneksi dengan kehidupan sosial yang konkrit dengan individu dan komunitas. Pada akhirnya, labelling juga dapat dibaca sebagai proses kontestasi perebutan legitimasi, serta proses bekerjanya kekuasaan (Takács, 20I7).

Wacana politik yang disampaikan ke publik membutuhkan kemasan yang tepat agar publik tertarik untuk mengikuti, memperdebatkan, dan kemudian ikut terlibat dalam mempromosikan wacana tersebut. Adanya uapaya untuk mengemas melalui wacana ini disebut dengan pembingkaian atau framing, di mana suatu masalah disajikan oleh seorang aktor, atau media untuk menarik perhatian, membuat peristiwa menjadi relevan, memberi makna dan menekankan pada isu tertentu (Eriyanto, 2002).

Pelabelan memiliki keterkaitan erat dengan framing karena agar label itu menjadi relevan membutuhkan pembingkaian khusus, mulai dari bagian mana yang perlu ditonjolkan, hingga penjelasan atas label yang kontekstual dan rasional kenapa label itu muncul. Gamson \& Modigliani (1989) merupakan salah satu sarjana yang mengembangkan analisis framing. Cara menjelaskan sebuah framing yang mereka gunakan mempunyai relevansi dengan label karena berkenaan dengan kemasan (package), berkaitan dengan perangkat pembingkaian (framing devices) dan perangkat penalaran (reasoning devices).

Framing devices terdiri atas metafora, frase yang menarik, kontras, dan menonjol (catchphrases), mengaitkan bingkai dengan contoh (exemplar), penggambaran isu bersifat konotatif berupa kosakata atau label (depictions) dan terakhir visualisasi yang mendukung isi atau pesan. Sedangkan, reasoning devices yang terdiri dari sebab-akibat (roots), premis dasar, klaim moralitas (appeal to principle), dan terakhir efek atau konsekuensi yang didapat dari pembingkaian (consequences). Dalam konteks politik pelabelan, framing devices tampil dalam bentuk frase atau kalimat yang membentuk pada gagasan atau ide tertentu.

Sedangkan reasoning device merujuk pada bagaimana dasar pembenaran dan penalaran yang dimunculkan untuk menjembatani label tersebut. Lewat proses 
penalaran ini, khalayak menerima pesan tersebut sebagai suatu kebenaran, rasional, dan wajar. Sebaliknya, tanpa penalaran maka label atau gagasan tersebut tampak aneh, dan justru menimbulkan kecurigaan (Eriyanto, 2002). Sehingga antara pembingkaian dan penalaran saling melengkapi satu sama lain, dan dalam sebuah label terdapat dua aspek tersebut.

Dalam relasi dan interaksi keseharian, kita semua adalah aktor yang memberikan label. Karena itu pula, kita dapat dilabeli. Begitu juga dalam relasi politik, frame dan label secara sederhana juga digunakan untuk mengkategorisasikan siapa lawan-kawan, memberi pembeda antara kita-mereka (Moncrieff, 2007). Lebih jauh, pelabelan juga turut membagi antara siapa pendukung-oposisi, mengklaim mayoritasminoritas dan lebih luas turut membentuk orientasi politik dan perilaku memilih.

Kekuatan pelabelan perlu dipahami untuk mencegah dan mengatasi konsekuesi terburuknya, serta memungkinkan mendorong pada proses yang memberikan keuntungan sosial politik. Hal ini mengindikasikan bahwa penggunaan label dan framing memerlukan kehati-hatian dan strategi yang tepat.

\section{Pelabelan dan Relasi In-group dan Out-group}

Kelompok sosial adalah sekumpulan individu yang memiliki identitas sosial yang sama atau memandang diri mereka sebagai anggota dari kategori sosial yang sama. Melalui proses perbandingan sosial, orang-orang yang mirip dengan diri sendiri disebut in-group, sedangkan orang yang berbeda dari diri sendiri dikategorikan sebagai kelompok luar atau out-group (Stets \& Burke, 2000).

Dalam konteks kehidupan sosial, seseorang dengan ketegori yang sama (ingroup) cenderung berperilaku sesuai dengan identitas kelompoknya, dan memandang kelompok lain yang berada di luar dirinya (out-group) dengan streotip tertentu. Menurut Tajfel \& Turner (2004) identifikasi yang demikian bersifat relasional dan komparatif, karena terdapat perbandingan. Misalnya, kelompok kami baik dan mereka adalah kelompok yang buruk.

Teori awal dalam keterkaitan antara perasaan dan identifikasi in-group dan antagonisme out-group didefinisikan sebagai "etnosentrisme" - ketika awal konsep ini diperkenalkan oleh Sumner (Brewer, 200I). Etnosentrisme dideskripsikan oleh Sumner sebagai karakteristik universal dari sebuah kelompok sosial berada. Definisi oleh Sumner tersebut berkembang pada empat proposisi. Pertama, kelompok sosial terorganisasi dalam kategori in-group dan out-group yang berlawanan (prinsip kategorisasi sosial). Kedua, individu menilai in-group secara positif dan menjaga hubungan yang kooperatif di antara anggota in-group (prinsip kepositifan in-group). Ketiga, perasaan positif in-group ditingkatkan melalui perbandingan sosial dengan outgroup yang mana atribut in-group dinilai lebih baik atau lebih superior daripada outgroup (prinsip perbandingan antar grup). Keempat, hubungan antara in-group dan out- 
group dikarakteristikkan oleh antagonisme, konflik dan saling menghina (prinsip permusuhan terhadap out-group)

Hal yang sama juga diungkap oleh Tajfel \& Turner (2004), yang menyebut konsep in-group dan out-group dalam ketegori dan identitas sosial dapat dilihat melalui beberapa karakteristik. Pertama, individu berusaha untuk mempertahankan atau meningkatkan harga diri mereka. Kedua, kelompok sosial dan keanggotaanya dikaitkan dengan konotasi nilai positif dan negatif. Oleh karena itu, identitas sosial dapat positif atau negatif sesuai dengan penilaian dari kelompok yang berkontribusi, baik individu maupun kolektif. Ketiga, evaluasi kelompok sendiri ditentukan dengan merujuk pada kelompok lain yang spesifik melalui perbandingan sosial dalam hal atribut dan karakteristik yang bernilai.

Dalam konteks politik praktis, pelabelan in-group dan out-group biasanya muncul dalam kampanye politik untuk menggambarkan kandidat dari kelompok sendiri maupun kandidat orang lain. Studi Budesheim, Houston, \& DePaola (1996) yang menyelidiki proses pesan politik dalam kampanye politik negatif, menunjukkan bahwa efektivitas berbagai jenis pesan serangan tergantung pada dua aspek utama. Pertama, afiliasi politik berkaitan sumber dan target pesan serangan. Kedua, pembenaran yang diberikan untuk serangan tersebut. Budesheim et al. (I996) menyebutkan bahwa konten pesan serangan negatif memengaruhi evaluasi kandidat dalam in-group, tetapi tidak pada kandidat out-group.

\section{Politik Pelabelan dalam Sejarah Politik Indonesia}

Dalam sejarah politik Indonesia, penyematan label pada kelompok atau individu merupakan praktik untuk menunjukkan perbedan politik, memberikan pemaknaan dan persepsi politik tertentu. Selain itu, label juga menjadi alat untuk menyerang kelompok tertentu yang dianggap berseberangan. Ketika Orde Lama, Presiden Soekarno, misalnya, menggunakan label "kontra-revolusioner" untuk menyebut pihak-pihak yang tidak setuju atau menolak konsep Nasionalisme, Agama, dan Komunisme (NASAKOM) yang dicetuskannnya. Lebih jauh, label ini juga digunakan untuk menyebut siapa yang tidak setuju terhadap Pancasila atau antiPancasila (Arifin, 2019; Soemohadiwidojo, 20I7).

Hal yang sama terjadi pada pemilu tahun 1995. Kontestan yang terdiri dari Partai Masyumi, PKI, PNI, dan Partai NU saling memberi makna satu sama lain melalui pelabelan. PKI menyebut Masyumi sebagai "partai penebar teror" dan "antidemokrasi". Sebaliknya, Masyumi menuduh PKI sebagai "partai kafir" dan "antek Moskow" (Feith, 1999).

Sedangkan pada masa Orde Baru, praktik politik pelabelan juga menjadi cara pemerintah untuk memberikan stigma pada kelompok atau individu tertentu. Beberapa label yang muncul diantaranya, "anti-Pancasila", "komunis/PKI", "subversif", dan "anti-pembangunan" (Anshori, 2008). Label yang diproduksi rezim 
Orde Baru ini bisa menyasar kelompok yang dianggap bertentangan dengan pemerintah.

Dalam konteks relasi antar kelompok Islam, pelabelan juga pernah terjadi. Penerimaan NU terhadap asas Pancasila, misalnya, menjadikan NU mendapatkan label "pengkhianat Islam" atau "bughat" (pemberontak) karena membantu berdirinya "Republik Indonesia Kafir" serta dianggap menerima konsep Nasionalisme, Agama, Komunisme (Nasakom). Label dan narasi tersebut dilakukan oleh kelompok pendukung Negara Islam Indonesia (NII) dan disebar kepada umat Islam di basis-basis gerilya NII (Al-Chaidar, I999; Alami, 2019).

Tokoh Masyumi dan NU juga saling memberi label berkaitan dengan sikap politik yang diambil. Misalnya, Masyumi menyebut NU dengan label "kolot”, "kuno”, "ortodoks" dan dianggap tidak bisa mengelola pemerintahan karena bodoh. Sedangkan tokoh NU sendiri menggambarkan Masyumi sebagai organisasi ekstrem dan tidak toleran dalam bekerjasama dengan kelompok diluar muslim. Tokoh NU juga menuduh Masyumi tidak mengikuti madzhab Sunni sehingga tidak dapat digolongkan dengan Ahlussunnah wal Jama'ah (Fealy, 20I2).

\section{Kelompok Islam di Dua Kubu Kontestan Pilpres 2014 dan 2019}

Polarisasi kelompok Islam yang memberi dukungan pada dua kubu yang berkontestasi sejak pemilu 20I4, sebagian besar dapat diamati berdasarkan pada interpretasi yang berbeda dari teologi politik Islam dan identitas daerah. Upaya memobilisasi isu agama tampak dari beberapa fenomena kampanye hitam yang menyerang Jokowi dan Prabowo. Jokowi, oleh sebagian kelompok Islam pendukung Prabowo, disebut sebagai pemimpin yang tidak memiliki kepercayaan Islam yang kuat dan berencana untuk mengimplementasikan kebijakan yang akan menekan kelompok Muslim. Sedangkan sebagian kelompok Islam pendukung Jokowi, mengkatogorisasikan kelompok di belakang Prabowo sebagai ekstremis agama yang ingin mengubah Indonesia menjadi negara Islam atau berbasis kekhilafahan. Hal ini pula yang dapat diidentifikasi mengerucutnya pelabelan politik di antara kelompok Islam.

Pada pemilu 2019, Jokowi yang berkontestasi kembali melawan Prabowo, memenangkan pemilu kembali dengan dukungan oleh kelompok Muslim yang tinggal di Jawa Timur dan Jawa Tengah, dua provinsi dengan penduduk terpadat. Banyak di antara mereka adalah anggota Nadhlatul Ulama (NU). Sementara itu, Prabowo didukung oleh Muslim konservatif yang sebagian besar terdapat di Jawa Barat, Banten, Sumatera dan Sulawesi. Banyak pendukung Prabowo merupakan mantan peserta Aksi Bela Islam pada 2016-20I7 (kemudian menyebut diri sebagai "Alumni 2I2") yang menuntut Ahok dipenjara karena dianggap menista agama Islam. Kelompok Islam yang paling mengemuka dalam gerakan ini adalah Front Pembela Islam (FPI) dan Forum Umat Islam (FUI). Para pendukung Prabowo selama kampanye 
juga aktif mengkampanyekan \#20I9GantiPresiden (diinisiasi oleh PKS), yang beberapa kali menggelar aksi jauh sebelum penetapan pasangan presiden, antara Maret hingga September 2018.

Dibawah tekanan untuk meningkatkan kepercayaan publik terhadap citra keislamannya, Jokowi memilih ulama sebagai calon wakil presiden, yakni Ma'ruf Amin, mantan ketua Majelis Ulama Indonesia (MUI) dan Rais Aam di NU. Sedangkan Prabowo, di samping didukung kelompok Alumni 2I2, PKS, dan PAN, juga menerima dukungan dari ulama populer - seperti Abdul Somad, Abdullah Gymnastiar (Aa Gym), dan Adi Hidayat. Para ustadz ini adalah pengguna internet aktif untuk menyebarkan ajaran mereka dan memiliki banyak pengikut media sosial.

Mobilisasi kelompok-kelompok Islam seperti NU di kubu Jokowi; dan FPI, FUI atau Alumni 212 di kubu Prabowo, menyebabkan kampanye presiden tahun 2019 diwarnai dengan beragam narasi politik (termasuk pelabelan) di antara kelompok Islam. Politik pelabelan yang telah dimulai sejak 20I4, menguat pada pemilu 2019.

\section{Praktik Pelabelan antar Kelompok Islam pada 2014-2019}

Dalam wacana politik yang berkembang sejak pemilihan presiden 20I4, pilkada DKI Jakarta 20I7, hingga pemilihan presiden 20I9, pelabelan antar kelompok Islam kerap muncul. Berdasarkan identifikasi yang dilakukan, setidaknya terdapat beberapa label yang dikonstruksi lewat wacana dan stigma antar di antara kelompok Islam.

Tabel I

Label dan Pengertian yang Melingkupi Antar Kelompok Islam

\begin{tabular}{|l|l|}
\hline \multicolumn{1}{|c|}{ LABEL } & \multicolumn{1}{c|}{ PENGERTIAN } \\
\hline Muslim Munafik & $\begin{array}{l}\text { Label ini merujuk pada pengertian bahwa seorang muslim, baik sebagai } \\
\text { kelompok maupun individu, yang memilih pemimpin di luar agama Islam } \\
\text { dianggap sebagai muslim munafik. }\end{array}$ \\
\hline $\begin{array}{l}\text { Partai Setan vs } \\
\text { Partai Allah }\end{array}$ & $\begin{array}{l}\text { Label "partai setan" ditujukan pada partai yang dinilai tidak sejalan dengan } \\
\text { kepentingan Islam, sedangkan "partai Allah" ialah partai yang mewakili } \\
\text { kepentingan kelompok Islam. }\end{array}$ \\
\hline $\begin{array}{l}\text { Bendera Tauhid } \\
\text { dan Bendera HTI }\end{array}$ & $\begin{array}{l}\text { Label ini merujuk pada satu obyek: bendera HTI. Tetapi karena bertuliskan } \\
\text { kalimat tauhid dalam bendera, maka diberi label "bendera Tauhid". } \\
\text { Sedangkan kelompok yang bersebarangan dengan pendukung label "bendera } \\
\text { Tauhid", tetap menganggap hal itu merupakan bendera HTI karena tetap } \\
\text { menggunakan warna hitam dan putih. }\end{array}$ \\
\hline $\begin{array}{l}\text { Islam Marah dan } \\
\text { Islam Ramah }\end{array}$ & $\begin{array}{l}\text { Pengertian "Islam marah" merujuk pada ekspresi keagamaan yang } \\
\text { menampilkan arogansi dan disertai dengan tindak "kekerasaan" saat } \\
\text { menyampaikan ajaran Islam. Sedangkan "Islam ramah" justru sebaliknya, } \\
\text { cara atau ekspresi keagamaan yang dilingkupi dengan pesan Islam yang } \\
\text { menjunjung perdamaian dan kemanusiaan. }\end{array}$ \\
\hline
\end{tabular}




\begin{tabular}{|l|l|}
\hline $\begin{array}{l}\text { Umat Sumbu } \\
\text { Pendek dan } \\
\text { Panjang }\end{array}$ & $\begin{array}{l}\text { Lebel "sumbu pendek" merupakan label lama yang mengkritik ekspresi } \\
\text { kelompok Islam yang dinilai terlalu cepat marah, tanpa pertimbangan yang } \\
\text { dalam. Sebaliknya "sumbu panjang" mengekspresikan kelompok Islam yang } \\
\text { lebih moderat dan toleran }\end{array}$ \\
\hline $\begin{array}{l}\text { Ulama yang jadi } \\
\text { cebong" }\end{array}$ & $\begin{array}{l}\text { Label ini memberikan pengertian bahwa ada tokoh atau pemuka agama Islam } \\
\text { yang sebelumnya berada dalam barisan pendukung Prabowo kemudian } \\
\text { beralih posisi mendukung Jokowi. }\end{array}$ \\
\hline $\begin{array}{l}\text { Kadrun (Kadal } \\
\text { Gurun) }\end{array}$ & $\begin{array}{l}\text { Label ini muncul dalam percakapan media sosial - yang biasanya dilakukan } \\
\text { oleh buzzer. Dalam pengertian terbatas, label Kadrun ditujukan kepada } \\
\text { kelompok atau individu yang tidak mendukung kebijakan Jokowi-Ma'ruf } \\
\text { Amin atau anti-pemerintah sekaligus merujuk pada preferensi ideologi } \\
\text { keagamaan dengan hadirnya isu khilafah dan radikalisme (DEA, 20I9) }\end{array}$ \\
\hline
\end{tabular}

Sumber: data diolah

Berdasarkan label yang diidentifikasi, ada beberapa hal yang dapat dijelaskan. Pertama, politik pelabelan antar kelompok Islam berkaitan erat dengan kontestasi dan konstelasi dukungan politik elektoral. Ekspresi dalam kontestasi politik dilakukan dengan membangun persepsi bersama baik kepada kelompok diri sendiri maupun kelompok orang lain. Persepsi kelompok sendiri dibangun dengan cara mencitrakan sebagai kelompok yang positif (label "bendera tauhid" atau "partai Allah"), sedangkan untuk kelompok lain dicitrakan negatif ("partai setan”, "muslim munafik” maupun "kadal gurun").

Kedua, pelabelan digunakan untuk membangun legitimasi terhadap diri sendiri, sekaligus delegitimasi terhadap kelompok Islam yang lain. Muncul narasi bahwa masing-masing kelompok mewakili kepentingan umat Islam dan berebut klaim sebagai kelompok yang berada dalam garis perjuangan yang benar. Pada label "Partai Allah vs Partai Setan", klaim dan legitimasi yang hendak diciptakan bahwa kelompok pendukung Prabowo adalah kelompok yang memperjuangkan aspirasi Islam, sedangkan kelompok Jokowi dianggap bertentangan dengan Islam. Upaya ini merupakan tujuan dari politik pelabelan, yakni mempertegas kategorisasi dan perbedaan antar kelompok.

Ketiga, label juga muncul sebagai bagian respon dari sebuah kebijakan pemerintah, serta merefleksikan sikap sebagai pendukung dan oposisi. Pembingkaian bahwa Jokowi tidak berpihak pada Islam didasarkan pada kebijakan Presiden Jokowi yang menerbitkan Perppu Nomor 2 Tahun 2017 tentang Perubahan atas UndangUndang Nomor I7 tahun 2013 tentang Organisasi Kemasyarakatan. Impilkasi dari Perppu tersebut mengakibatkan pembubaran HTI. Sekalipun keputusan pemerintah mendapat dukungan dari ormas Islam seperti NU (Tirto.id, 2017), namun framing tentang Presiden Jokowi yang tidak berpihak kepada Islam terus dilakukan oleh kelompok Islam lain pendukung HTI. Label yang berkenaan dengan ini pun muncul, misalnya "Anti-Islam". Kondisi ini menunjukkan bahwa politik pelabelan juga berkaitan dengan proses pembuatan kebijakan. 
Keempat, sebagian label di kalangan kelompok Islam juga muncul atas reaksi atas sikap sosial dan politik yang dikembangkan oleh kelompok lain. Label "Islam Marah" hendak mengasosiasikan kelompok Islam tertentu bahwa mereka identik dengan kekerasan. Sedangkan label "Islam Ramah" digunakan sebagai lawan dari label "Islam Marah". Demikian pula dengan label "umat sumbu pendek" yang digunakan untuk menandai kelompok Islam yang diidentikkan dengan dangkal, reaksioner dan tidak toleran. Segregasi di antara kelompok Islam dalam kedua kubu kandidat calon presiden memberi ruang bagaimana antar kelompok memberikan definisi, tafsiran, dan streotip antar kubu.

\section{Konteks Kemunculan Label Antar Kelompok Islam}

Label merupakan fitur dari proses komunikasi sosial, sekaligus bagian dari proses politik karena melibatkan hubungan kekuasaan dan interaksi hegemonik. Hegemoni ini dikonstuksi dan diartikulasikan melalui berbagai praktik komunikasi (Wood, 1985), misalnya melalui pemberitaan media, konten media sosial, dan beragam ekspresi lain yang ada di ruang publik. Bagaimana muncul dan digunakan dijelaskan dalam tabel berikut:

Tabel 2

Politik Pelabelan dan Latar Belakang Kemunculan Label Antar Kelompok Islam

\begin{tabular}{|c|c|c|c|c|}
\hline Label & $\begin{array}{c}\text { Waktu/ } \\
\text { Momentum }\end{array}$ & Alasan & $\begin{array}{l}\text { Inisiator/ yang } \\
\text { Mempopulerkan }\end{array}$ & Konsekuensi \\
\hline $\begin{array}{l}\text { Muslim } \\
\text { Munafik }\end{array}$ & $\begin{array}{l}\text { Menjelang } \\
\text { Pemilihan } \\
\text { Gubernur DKI } \\
\text { Jakarta 20I7 }\end{array}$ & $\begin{array}{l}\text { Ahok dianggap } \\
\text { melakukan penistaan } \\
\text { terhadap agama Islam } \\
\text { dan juga dari kalangan } \\
\text { non-Muslim. Sehingga } \\
\text { muslim di Jakarta yang } \\
\text { memilih Ahok dianggap } \\
\text { munafik. }\end{array}$ & $\begin{array}{c}\text { Kelompok kontra } \\
\text { Ahok }\end{array}$ & $\begin{array}{l}\text { Ancaman } \\
\text { provokatif bagi } \\
\text { warga muslim } \\
\text { Jakarta yang } \\
\text { memilih Ahok } \\
\text { dalamPilgub DKI } \\
\text { tidak akan } \\
\text { dishalatkan } \\
\text { jenazahnya ketika } \\
\text { meninggal. }\end{array}$ \\
\hline $\begin{array}{l}\text { Partai } \\
\text { Setan dan } \\
\text { Partai } \\
\text { Allah }\end{array}$ & $\begin{array}{l}\text { April 20I8. } \\
\text { Keterkaitan } \\
\text { dengan koalisi } \\
\text { partai. }\end{array}$ & $\begin{array}{l}\text { Pemerintahan Jokowi } \\
\text { dianggap melakukan } \\
\text { pemisahan agama dan } \\
\text { politik, termasuk tidak } \\
\text { peka terhadap } \\
\text { kepentingan Islam. } \\
\text { Sehingga partai } \\
\text { pendukung Jokowi } \\
\text { dianggap tidak berpihak } \\
\text { pada kepentingan } \\
\text { Islam. Sebaliknya partai } \\
\text { pengusung Prabowo } \\
\text { dianggap mewakili } \\
\text { kepentingan Islam. }\end{array}$ & $\begin{array}{c}\text { Amien Rais } \\
\text { (Ketua Penasihat } \\
\text { Persaudaraan } \\
\text { Alumni 2I2) }\end{array}$ & $\begin{array}{l}\text { Pro-kontra dalam } \\
\text { diskursus partai } \\
\text { politik yang } \\
\text { mewakili } \\
\text { kepentingan } \\
\text { kelompok Islam } \\
\text { dan memberi } \\
\text { kritik terhadap } \\
\text { partai pendukung } \\
\text { pemerintah. }\end{array}$ \\
\hline $\begin{array}{l}\text { Bendera } \\
\text { HTI dan }\end{array}$ & $\begin{array}{l}\text { Oktober } 2018 . \\
\text { Pasca } \\
\text { pembubaran }\end{array}$ & $\begin{array}{l}\text { Anggota Banser dan } \\
\text { Ansor menyebut } \\
\text { bendera yang dibakar }\end{array}$ & $\begin{array}{l}\text { Banser, Ansor, } \\
\text { FPI dan GNPF }\end{array}$ & $\begin{array}{l}\text { Mobilisasi aksi } \\
\text { protes terhadap } \\
\text { pembakaran }\end{array}$ \\
\hline
\end{tabular}




\begin{tabular}{|c|c|c|c|c|}
\hline $\begin{array}{l}\text { Bendera } \\
\text { Tauhid }\end{array}$ & $\begin{array}{l}\text { HTI dan } \\
\text { terjadinya } \\
\text { pembakaran } \\
\text { bendera pada } \\
\text { peringatan hari } \\
\text { santri di Garut. }\end{array}$ & $\begin{array}{l}\text { mencerminkan simbol } \\
\text { HTI yang sudah } \\
\text { dilarang di Indonesia, } \\
\text { sedangkan FPI dan } \\
\text { GNPF menyebut } \\
\text { bendera yang dibakar } \\
\text { sebagai simbol tauhid }\end{array}$ & & $\begin{array}{l}\text { bendera } \\
\text { HTI/tauhid dan } \\
\text { aksi bela bendera } \\
\text { tauhid. }\end{array}$ \\
\hline $\begin{array}{l}\text { Islam } \\
\text { Marah } \\
\text { dan Islam } \\
\text { Ramah }\end{array}$ & Pasca reformasi & $\begin{array}{l}\text { Fenomena kelompok } \\
\text { Islam yang mencitrakan } \\
\text { Islam dengan cara } \\
\text { arogan, seperti ceramah } \\
\text { yang dipenuhi dengan } \\
\text { ekspresi marah-marah } \\
\text { maupun aksi } \\
\text { "kekerasan" seperti } \\
\text { sweeping dan razia } \\
\text { tempat-tempat yang } \\
\text { dianggap corong } \\
\text { maksiat. }\end{array}$ & $\begin{array}{c}\text { Abdurrahman } \\
\text { Wahid (Gus Dur) }\end{array}$ & $\begin{array}{l}\text { Label lama ini } \\
\text { kerap muncul } \\
\text { untuk menyindir } \\
\text { dan } \\
\text { mengkategorikan } \\
\text { kelompok Islam } \\
\text { yang dicitrakan } \\
\text { memiliki ekspresi } \\
\text { keagamaan } \\
\text { intoleran dan } \\
\text { reaktif. }\end{array}$ \\
\hline $\begin{array}{l}\text { Umat } \\
\text { Sumbu } \\
\text { Pendek } \\
\text { dan } \\
\text { Panjang }\end{array}$ & Pasca reformasi & $\begin{array}{l}\text { Sumbu pendek } \\
\text { menggambarkan umat } \\
\text { Islam yang reaksioner, } \\
\text { mudah diprovokasi, dan } \\
\text { tidak toleran terhadap } \\
\text { perbedaan. Sebaliknya } \\
\text { umat sumbu panjang } \\
\text { lebih toleran dan tidak } \\
\text { mudah terprovokasi. }\end{array}$ & $\begin{array}{c}\text { Khairuddin } \\
\text { Tahmid (Wakil } \\
\text { Rais Syuriyah } \\
\text { PWNU Lampung) }\end{array}$ & $\begin{array}{l}\text { Kritik terhadap } \\
\text { kelompok Islam } \\
\text { yang } \\
\text { mengedepankan } \\
\text { identitas namun } \\
\text { kurang toleran } \\
\text { (umat sumbu } \\
\text { pendek). }\end{array}$ \\
\hline $\begin{array}{l}\text { Ulama } \\
\text { yang jadi } \\
\text { "Cebong" }\end{array}$ & $\begin{array}{l}\text { Pasca Pilpres } \\
2019\end{array}$ & $\begin{array}{l}\text { Digunakan untuk } \\
\text { menyebut ustaz atau } \\
\text { ulama yang sebelumnya } \\
\text { mendukung Prabowo, } \\
\text { tapi kemudian beralih } \\
\text { dukungan terhadap } \\
\text { Jokowi. }\end{array}$ & $\begin{array}{l}\text { Slamet Arif, } \\
\text { Ketua Umum } \\
\text { Persaudaraan } \\
\text { Alumni (PA) 2I2 }\end{array}$ & $\begin{array}{l}\text { Merefleksikan } \\
\text { pecahnya aliansi } \\
\text { tokoh pendukung } \\
\text { Prabowo. }\end{array}$ \\
\hline $\begin{array}{l}\text { Kadrun } \\
\text { (Kadal } \\
\text { Gurun) }\end{array}$ & $\begin{array}{l}\text { Menjelang } \\
\text { Pilpres 20I9. } \\
\text { Muncul di } \\
\text { media sosial. }\end{array}$ & $\begin{array}{l}\text { Label ini tidak jelas } \\
\text { muncul dari mana } \\
\text { awalnya, namun label } \\
\text { ini kerap diidentikkan } \\
\text { untuk menggambarkan } \\
\text { preferensi sebagian } \\
\text { kelompok Islam yang } \\
\text { mengusung isu khilafah } \\
\text { dan radikalisme } \\
\text { sekaligus dianggap anti } \\
\text { terhadap pemerintahan } \\
\text { Jokowi. }\end{array}$ & Anonim & $\begin{array}{l}\text { Tiap } \\
\text { orang/sekelompok } \\
\text { orang yang } \\
\text { melakukan kritik } \\
\text { terhadap } \\
\text { pemerintahan } \\
\text { Jokowi dengan } \\
\text { embel-embel atau } \\
\text { atribut Islam } \\
\text { dilabeli Kadrun. }\end{array}$ \\
\hline
\end{tabular}

Sumber: data diolah

Pada tabel 2 dapat dilihat bahwa label memiliki hubungan kausalitas dengan kejadian-kejadian tertentu di sepanjang 20I4-20I9. Suatu label berkenaan dengan hubungan sebab akibat dan menjadi penjelas mengapa label bisa muncul dan digunakan. Hal ini, tak lepas dari konteks atau kejadian politik yang sebelumnya muncul dan dikemas dengan cara tertentu untuk membawa kembali ingatan tentang konteks atau kejadian tersebut. Satu label dengan label yang lain saling berkelindan. 
Suatu label berkenaan dengan label lain yang sebelumnya pernah ada. Misal, label yang disematkan kepada Presiden Jokowi sebagai "anti-Islam" (Sindonews, 20I7)dikaitkan dengan label "PKI" yang sebelumnya digunakan. Produksi label aktif dilakukan baik oleh politisi, maupun tokoh-tokoh yang menyandang gelar ulama dan ustaz. Konteks-konteks tersebut pada akhirnya digunakan dalam mobilisasi kepentingan elektoral.

Dalam konteks politik sepanjang 2014 sampai 20I9, "ulama" menjadi salah satu term yang banyak digunakan baik untuk memperoleh dukungan, maupun melemahkan dukungan lawan. Label "ulama" yang kemudian disandingakan dengan term lain, seperti "ijtima ulama" atau "restu ulama", yang kemudian menjadi praktik pelabelan yang betujuan politis. Kondisi ini masuk dalam perangkap arena simbol (syimbolic arena), di mana antar kelompok berusaha menarik suatu permasalahan dengan menggunakan metafora dan frase untuk membingkai suatu kompleksitas permasalahan ((Gamson \& Modigliani, 1994). Awalnya ulama adalah simbol otoritas di bidang keagaman, namun kemudian otoritas itu digeser pada aspek politik praktis untuk menarik simpati dan dukungan publik.

Lebel lain yang juga mencerminkan konstruksi sosial dan bersifat hegemonik ialah "muslim munafik". Melalui label ini tampak adanya usaha yang dilakukan oleh kelompok Islam untuk manarik defenisi “munafik” yang awal pengertiannya adalah mengatakan sesuatu yang tidak sesuai dengan perbuatannya atau bermuka dua (Nasional, 2008), kemudian digiring pada aspek preferensi politik. Terlihat ada upaya perluasan makna dan konsepsi, yang suatu frase tertentu memiliki makna lain, kemudian di perluas maknanya melalui rasionalisasi yang dihubungkan dengan realitas politik yang kompleks. Demikian dengan label "kadrun" yang diasosiasikan kepada kelompok tertentu yang dianggap memiliki preferensi keagamaan dan dianggap bertentangan dengan negara. Label ini mencerminkan adanya konstruksi sosial untuk menggambarkan stereotip buruk terhadap kelompok atau individu yang dianggap kearab-araban, dan dangkal. Kadangkala label ini juga disematkan kepada seseorang yang kritis terhadap kebijakan pemerintah dan dianggap bagian dari gerakan 2 I2 dan 4II. Terjadi perluasan makna sesuai dengan narasi politik yang dimunculkan.

Melalui deskripsi di atas, tampak bahwa pelabelan menjadi praktik ideologis karena juga mengkonstruksi realitas sosial dan pola kognitif, persepsi serta emosi. Sebagai upaya memberi kategorisasi atau citra tertentu, label secara inheren menciptakan divisi eksklusif, mengingat penciptaan label, terdapat konstruksi ideologis yang jelas tentang "kita" versus "mereka" atau bahkan "mereka" versus "mereka yang lain". Dengan demikian, pelabelan juga memanisfestasikan segregasi kelompok dan kepentingan yang ingin dikejar oleh para aktor dalam situasi tertentu, terutama pada tujuan elektoral. 


\section{Manifestasi Segregasi Antar Kelompok Islam Melalui Label}

Karakter religiusitas masyarakat Indonesia memiliki konsekuensi penting secara politis. Agama menjadi bagian dari sosialisasi dan mendorong partisipasi sosial politik (Mujani, Liddle, R. W., \& Ambardi, 2018). Dalam kehidupan dan aktivitas keseharian, ekspresi kesalehan umat muslim di Indonesia tampak di depan umum. Hal ini dapat berbeda dalam ekspresi dan aktivitas politik. Meski sebagian besar aktivitas sosial dan ekonomi tidak lepas dari preferensi keislaman, seperti sekolah Islam, bank Syariah, bahkan pada aspek mode, tetapi hal berbeda tampak dalam penyuaraan aspirasi dan aktivitas politik. Masyarakat Islam Indonesia tampak terpolarisasi ketika terlibat dalam politik.

Ekspresi kesalehan di tengah umat Islam yang terpolarisasi, justru menyediakan sumber daya bagi mobilisasi oleh elite dan partai politik yang mengklaim mewakili kepentingan Muslim. Upaya mobilisasi tersebut tampak pada Pilpres 20I4 dan 20I9, serta beberapa pilkada di daerah yang diwarnai isu agama, termasuk Pilgub DKI Jakarta pada 2017 (Ramadlan \& Masykuri, 20I8), di mana polarisasi masyarakat dan organisasi Islam mengubah ekspresi keisalaman menjadi sumber daya politik.

Kasus yang terjadi di Pilkada Jakarta 2017, misalnya, menggambarkan bagaimana politik identitas dan pelabelan di satu sisi mengekspresikan perasaan khawatir dan ancaman marginalisasi ekonomi yang dimunculkan apabila Ahok terpilih kembali, seperti penggusuran. Di sisi yang lain sentimen agama dan etnis menjadi bahan bakar dalam mobilisasai dukungan. Sehingga muncul kampanye "Saya Muslim Saya Memilih Anies-Sandi" (Muhtadi, 20I8; Sari, 20I6).

Dalam konteks politik, praktik pelabelan merupakan bagian dari ekspresi atas polarisasi politik dan politik identitas Islam. Politik identitas dalam hal ini dimaknai sebagai penggunaan identitas kolektif, baik agama, etnis, budaya, gender atau identitas kolektif lainnya untuk meningkatkan kesadaran diri kelompok dan juga memberi mereka kekuatan politik supaya diperhitungkan di arena politik (Wiarda, 20I4). Dalam politik identitas terdapat perasaan yang ditonjolkan bersama tentang apa yang dirasakan oleh kelompok, misalnya perasaan diskriminasi dan ketidakadilan yang dialami. Bahkan dalam batas-batas tertentu, politik identitas mencuat dalam bentuk gagasan tentang separatisme (Maarif, Ali-Fauzi, \& Panggabean, 20Io).

Praktik politik pelabelan antar kelompok Islam di Indonesia seperti yang dijelaskan di atas, setidaknya merefleksikan dua hal: Pertama, meski berbasis agama yang sama, tetapi perbedaan preferensi politik kelompok Islam semakin terekspresi dengan jelas. Label seperti "muslim munafik" atau "ulama yang sudah jadi cebong" merupakan contoh bagaimana kelompok Islam terfragmentasi dengan tegas akibat mobilisasi dukungan politik. Label-label yang bersifat dikotomis menunjukkan bahwa politik identitas menguat meski pada keyakinan atau agama yang sama. 
Penggunaan label kemudian menjadi instrumen dalam membentuk dukungan elektoral. Hal tersebut misalnya dapat diamati dari tren penurunan suara Jokowi dimana berdasarkan survei LSI Denny JA pada Agustus 2018 memperoleh dukungan sebesar 52,7\%, turun menjadi $49,5 \%$ di Januari 2019 di daerah kantong muslim (Tempo.co, 2019). Jokowi masih dipersepsikan sebagai anti-Islam atau tidak ramah terhadap kelompok Islam.

Kedua, meski berada dalam momen-momen elektoral, tetapi segregasi antar kelompok Islam juga memiliki kontestasi ideologis. Diluar pemilu, hal tersebut tampak pada pembuatan kebijakan. Misalnya pada dukungan atau penolakan terhadap ideologi dan organisasi HTI, usulan pendirian negara Islam, atau penerapan syariat Islam sebagai hukum positif di Indonesia.

Perdebatan label bendera sebagai "bendera HTI" dengan "bendera tauhid" merupakan polemik ideologis yang berkembang sebelum pemilu 2019, di mana antar kelompok Islam berusaha memberikan penafsiran atas eksistensi HTI. Kelompok Islam seperti Ansor-NU yang menyebut sebagai “bendera HTI”, mengganggap ajaran, termasuk sikap politik HTI yang hendak menegakkan khilafah bertentangan dengan cita-cita pendirian negara Indonesia. Sedangkan tokoh-tokoh FPI dan GNPF memaknai sebagai "bendera tauhid" yang secara tersirat memiliki kesamaan sikap politik yakni dukungan terhadap penerapan syariat Islam dalam kehidupan politik Indonesia.

Kemunculan label pada akhirnya tidak lepas dari situasi spesifik dan historis. Tujuan pelabelan sebagai upaya meraih tujuan politik dilakukan melalui penandaan, pengkategorisasian, dan pemaknaan sosial, melalui kontingensi sosial, historis dan politik. Dengan cara ini, makna yang terkait melekat pada label, membentuk konstruksi sosial karena hasil pelabelan atau kontestasi antar label membentuk sentimen, serta upaya menciptakan perasaan solidaritas (konteks in-group), sekaligus curiga, ancaman dan kebencian (konteks out-group).

\section{Penutup}

Politik pelabelan dalam kelompok Islam sepanjang tahun 20I4-2019 memanifestasikan adanya segregasi yang tegas di antara kelompok Islam. Pada pemilu presiden 2014 dan 20I9, dukungan kelompok Islam terpecah kepada Jokowi dan Prabowo Subianto. Segregasi antara kelompok Islam juga menguat dalam momenmomen politik di luar pemilu, misalnya, dalam pemilihan Gubernur DKI Jakarta 20I7, pembubaran HTI, maupun respon atas kebijakan pemerintah. Label menjadi instrumen dan penanda segregasi antar kelompok Islam di Indonesia.

Penggunaan label digunakan pada beberapa momen politik tertentu diproduksi oleh elite melalui media sosial, ceramah agama, atau kampenye politik. Terdapat dua isu terkait politik pelabelan antar kelompok Islam. Pertama, label berhubungan dengan konteks, hubungan kausalitas, dan tujuan atau konsekuensi dari 
pelabelan. Label merefleksikan pembingkaian tertentu dan pembeda antar kelompok. Label menjadi penanda, membentuk bingkai dalam membentuk preferensi dan sikap politik, serta memberi petunjuk pada siapa kawan dan lawan. Kedua, segregasi dan polarisasi politik di antara kelompok-kelompok Islam selama 20I4-20I9 di Indonesia termanifestasi melalui konstruksi dan produksi berbagai label. Melalui label, sentimen agama dan perbedaan antar kelompok Islam menjadi instrumen untuk mobilisasi atau menggerus dukungan politik lawan dalam politik elektoral.

Politik pelabelan sebagai bagian dari instumen dan strategi politik, terus menerus diproduksi sebagai bagian dari merawat perasaan in-group dan out-grup. Perasaan berbeda dengan kelompok lain menjadi penting sebagai bagian dari instrumen serta sumber daya mobilisasi dukungan elektoral. Hal ini yang menjadikan label terus direproduksi baik melalui isu-isu di media sosial maupun momen-momen aktivitas politik riil. Walaupun, hal ini tentu memiliki berbagai bias politik dan ideologi karena dibangun melalui asumsi subyektif dan sentimen politik di luar pertimbangan pilihan rasional serta dibangun di atas identitas keagamaan (Islam).

\section{Ucapan Terima Kasih}

Terima kasih kepada teman-teman Pusat Kajian Media, Literasi, dan Kebudayaan (PUSKA MELEK) FISIP Universitas Brawijaya yang terlibat dalam diskusi penyusunan awal artikel ini.

\section{Pendanaan}

Penulis tidak menerima bantuan pembiayaan atau dana untuk penelitian, kepenulisan (authorship), dan publikasi dari pihak manapun

\section{Daftar Pustaka}

Al-Chaidar. (1999). Pemikiran politik proklamator negara Islam Indonesia SM Kartosoewirjo: fakta dan data sejarah Darul Islam. Darul Falah.

Alami, A. F. (2019). Bersama Menggempur NU. Retrieved from https:/www.gatra.com/detail/news/443104/politik/bersama-menggempur-nu

Ambardi, K., Mujani, S., \& Liddle, R. W. (2012). Kuasa Rakyat: Analisis tentang Perilaku Memilih dalam Pemilihan Legislatif dan Presiden Indonesia Pasca Orde Baru. Jakarta: Mizan.

Anshori, D. S. (2008). Hegemoni dan Dominasi Bahasa Pejabat Dalam Media Massa Pasca Orde Baru: Analisis Wacana Kritis Tentang Idiom Politik di Indonesia. In Makalah disajikan dalam Seminar dan Lokakarya Nasional, diselenggarakan oleh Prodi Pendidikan Bahasa Indonesia SPS UPI (Vol. 30).

Arifin, S. (2019). Islam, Populisme dan Masa Depan Demokrasi di Indonesia. Maarif, I4(I), 9-28.

Aspinall, E., Dettman, S., \& Warburton, E. (20II). When Religion Trumps Ethnicity: A 
Regional Election Case Study From Indonesia, I9(I), 27-58. https://doi.org/I0.5367/sear.20II.0034

Azra, A. (2004). Political Islam in Post-Soeharto Indonesia. In Islamic Perspectives on the New Millennium (V. Hooker, pp. I33-I49). ISEAS-Yusof Ishak Institut.

Backes, U. (2007). Meaning and Forms of Political Extremism. Středoevropské Politické Studie, 9(4), 242-262.

Beach, D. (2017). Process-Tracing Methods in Social Science. In Oxford research encyclopedias of politics: Qualitative political methodology (William R.). Oxford: Oxford University Press.

Brewer, M. B. (200I). In Group Identification and Intergroup Conflict: When Does Ingroup Love Become Outgroup Hate? In Social Identity, Intergroup Conflict, and Conflict Reduction (R Ashmore,). New York: Oxford Univ. Press. In press.

Budesheim, T. L., Houston, D. A., \& DePaola, S. J. (1996). Persuasiveness of in-group and out-group political messages: The case of negative political campaigning. Journal of Personality and Social Psychology, 70(3), 523-534.

Eriyanto, A. F. (2002). Analisis Framing: Konstruksi, Ideologi, dan Politik Media. Yogyakarta: LKiS.

Eyben, R. (2007). Labelling People for Aid. In The Power of Labelling: How People Are Categorized and Why It Matters (Joy Moncri). EARTHSCAN.

Fealy, G. (2012). Ijtihad Politik Ulama; Sejarah NU 1952-I967. Yogyakarta: LKiS.

Feith, H. (1999). Pemilihan Umum 1955 di Indonesia. Jakarta: Kepustakaan Populer Gramedia.

Gamson, W. A., \& Modigliani, A. (1989). Media Discourse and Public Opinion on Nuclear Power: A Constructionist Approach. American Journal of Sociology, 95(I), I37.

Gamson, W. A., \& Modigliani, A. (1994). The Changing Culture of Affirmative Action. In Equal Employment Opportunity: Labor Market Discrimination and Public Policy (Paul Burst). New York: Aldine De Gruyter.

Hasan, N. (2008). Laskar Jihad; Islam, Militansi dan Pencarian Identitas di Indonesia PascaOrde Baru. Jakarta: LP3ES dan KITLV.

Hosen, N. (2005). Religion and the Indonesian Constitution: A Recent Debat. Journal of Southeast Asian Studies, 419-440.

Karim, A. G. (2019). Mengelola Polarisasi Politik dalam Sirkulasi Kekuasaan di Indonesia: Catatan bagi Agenda Riset. Politika: Jurnal Ilmu Politik, Io(2), 215-228.

Karim, M. R. (1999). Negara dan Peminggiran Islam Politik: Suatu Kajian Mengenai Implikasi Kebijakan Pembangunan bagi Keberadaan "Islam Politik" di Indonesia era I970-an dan I980-an. Yogyakarta: Tiara Wacana Yogya.

King, D. Y. (2003). Half-Hearted Reform: Electoral Institutions and the Struggle for Democracy in Indonesia. Westpor: Greenwood Publishing Group.

Maarif, A. S., Ali-Fauzi, I., \& Panggabean, S. R. (20I0). Politik Identitas dan Masa Depan Pluralisme Kita. Centre for the Study of Islam and Democracy.

Moncrieff, J. (2007). Labelling, Power and Accountability: How and Why 'Our' 
Categories Matter. In The Power of Labelling: How People Are Categorized and Why It Matters (Joy Moncri). London: Earthscan.

Muhtadi, B. (20I8). Politik Identitas dan Mitos Pemilih Rasional. Jurnal MAARIF.

Mujani, S., Liddle, R. W., \& A., \& Ambardi, K. (2018). Voting Behavior in Indonesia Since

Democratization: Critical Democrats. New York: Cambridge University Press.

Nasional, P. B. D. P. (2008). Kamus Besar Bahasa Indonesia (KBBI). Jakarta: Gramedia.

Porter, D. (2004). Managing Politics and Islam in Indonesia. London: Routledge.

Ramadlan, F. S., \& Masykuri, R. (2018). Marketing Isu Agama Dalam Pemilihan Kepala Daerah Di Indonesia 2015-2018. Jurnal Penelitian Politik, 15(2), 249-265.

Sajjad, T. (2018). What's in A Name? 'Refugees', 'Migrants' and the Politics of Labelling. Race E Class, 6o(2), 40-62.

Sari, E. (20I6). Kebangkitan Politik Identitas Islam Pada Arena Pemilihan Gubernur Jakarta. KRITIS: Jurnal Ilmu Sosial Dan Ilmu Politik Universitas Hasanuddin, I(I), I45I56.

Schreier, M. (2012). Qualitative Content Analysis in Practice. Sage publications.

Shestopal, E. (20I4). Qualitative and Quantitative Methods in Political Perception Studies Paper presented to the ECPR General conference, Glasgow.

Sindonews. (2017). Ustaz Felix Siauw Ungkap Indikasi Pemerintahan Jokowi Anti-

Islam. Retrieved from https://nasional.sindonews.com/berita/I203662/I2/ustazfelix-siauw-ungkap-indikasi-pemerintahan-jokowi-anti-islam

Soemohadiwidojo, R. (20I7). Soekarno Sang Singa Podium. Jogjakarta: Second Hope.

Stets, J. E., \& Burke, P. J. (200o). Identity Theory and Social Identity Theory. Social Psychology Quarterly, 224-237.

Tajfel, H., \& Turner, J. C. (2004). The Social Identity Theory of Intergroup Behavior. In Key readings in social psychology. Political psychology: Key readings (J. T. Jost, pp. 276293). Psychology Press.

Takács, Á. (2017). Biopolitics and Biopower: The Foucauldian Approach. In Bioethics and Biopolitics Theories, Applications and Connections (Péter Kaku). Switzerland: Springer and Its Contemporary Relevance.

Tempo.co. (20I7). Masjid Tolak Salatkan Pemilih Ahok, Begini Reaksi Warga. Retrieved from ttps://metro.tempo.co/read/850II5/masjid-tolak-salatkan-pemilihahok-begini-reaksi-warga

Tempo.co. (2019). LSI Denny JA Sebut Jokowi Masih Dibayangi Sentimen Anti-Islam. Wiarda, H. J. (20I4). Political Culture, Political Science, and Identity Politics: An Uneasy Alliance. Ashgate Publishing, Ltd.

Wood, G. (1985). The Politics of Development Policy Labelling, Development and Change. International Institute of Social Studies, I6(3), 347-373.

Wood, G. (2017). Label, Welfare Regimes and Intermediation: Contesting Formal Power. In The Power of Labelling: How People Are Categorized and Why It Matters (Joy Moncri). London: Earthscan. 


\section{Tentang Penulis}

Romel Masykuri adalah Peneliti Pusat Kajian Media, Literasi dan Kebudayaan, Fakultas Ilmu Sosial dan Ilmu Politik, Universitas Brawijaya.

M. Fajar Shodiq Ramadlan adalah dosen Ilmu Politik, Fakultas Ilmu Sosial dan Ilmu Politik, Universitas Brawijaya. Penulis memiliki area riset seputar partai politik, pemilu, dan gerakan sosial. 